\title{
Reconstructing Typhoons Affecting Japan in 1877
}

\author{
Michael J. GROSSMAN*, Masumi ZAIKI**, \\ Takehiko MIKAMI ${ }^{* * *}$ and Cary MOCK ${ }^{* * * *}$
}

[Received 24 July, 2017; Accepted 18 February, 2018]

\begin{abstract}
Historical documentary sources provide important data for the reconstruction of typhoons before the collection of systematic instrumental records by official government meteorological agencies. In this paper, we describe five sources that we use to provide details about typhoons affecting the four main islands of Japan in 1877. The sources described are: 1) English-language newspapers published in Japan; 2) the Historical Weather Database for Japan; 3) Japanese lighthouse records; 4) logbooks from British and American ships; and 5) data tables from the Imperial Meteorological Observatory in Tokyo. We then show the data and reports from these sources that provide evidence for four typhoons (June 11, July 26-27, August 25-27 and October 11) that affected Japan in 1877. All five sources give information about these typhoons indicating that the historical sources can provide a detailed record of storms affecting Japan including information about location and storm track, wind speed, barometric pressure, and damage. Such historical documentary records of typhoons can be used to extend our knowledge of typhoon frequency, intensity and behavior into periods that previously lacked information.
\end{abstract}

Key words : tropical cyclones, typhoons, historical climatology, Japan, climatic reconstruction, documentary sources

\section{Introduction}

Annual tropical cyclone (typhoon) landfalls and close approaches are a constant threat to life and property in Japan. According to the Japanese Meteorological Agency (JMA), between 1951-2016, an annual average of 26 typhoons formed in the Western North Pacific with 11.5 of those storms eventually coming within $300 \mathrm{~km}$ of a Japanese meteorological observatory (JMA, 2017a, b) . An average of 3.1 typhoons per year make landfall (crossing the coastline) on one of the four main islands (Honshu, Hokkaido, Kyushu, and Shikoku) (JMA, 2017c). These storms bring strong winds, heavy rains, and high waves to Japan resulting in wind damage, floods and landslides. A database of typhoon damage, based on the Japan Rika Nenpyo (Chronological Scientific Tables), indicates that the 159 damaging typhoons affecting Japan from 1951-2016 resulted in 14,952 dead or missing, 76,160 injured, and damages of more than 4.6 billion Japanese yen (Kitamoto, 2017).

Given the threat that typhoons present to Japan, it is critical to learn as much as possible about their characteristics to better enable prediction of their behavior and potential responses to global climate change in the $21^{\text {st }}$ century. For understanding tropical cyclone behavior

\footnotetext{
* Southern Illinois University Edwardsville, Edwardsville, IL, 62026, U.S.A.

** Faculty of Economics, Seikei University, Musashino, 180-8633, Japan

*** Faculty of Liberal Arts, Teikyo University, Hachioji, 192-0395, Japan

**** University of South Carolina, Columbia, SC, 29208, U.S.A.
} 
over extended time periods and under differing climatic conditions, it is important to utilize as long a record as possible. Our research uses historical instrumental and documentary data to provide information about typhoons affecting Japan before the period of continuous instrumental records in the late $19^{\text {th }}$ century. Here, we review the types of data used and demonstrate how they can be employed in reconstructing typhoons affecting Japan in 1877. We consider a typhoon to have affected Japan if evidence indicates it made landfall or came close enough to land to generate conditions that suggest a typhoon occurred. The year 1877 is chosen to exemplify our historical approach to reconstructing part of the typhoon record based the availability of historical data.

\section{Background}

The powerful impacts that tropical cyclones can have on the countries that are affected by them have led to extensive efforts to document and study these storms. An important part of these efforts has included extending the record of tropical cyclones into past centuries using historical documentary and instrumental records. For example, for the North Atlantic Basin, García-Herrera et al. (2004, 2005, 2007a) used Spanish and British documentary sources to detail historical Atlantic and Caribbean hurricanes and Chenoweth (2014) used extensive historical sources to compile a record of North Atlantic tropical cyclones between 1851-1898 and compared this new record with HURDAT2.

For specific storms, Mock (2004, 2008) used documentary records to reconstruct historical hurricanes in South Carolina and Louisiana, U.S.A. since the late 18 th century. Mock et al. (2010) used ship logbooks to reconstruct the path, intensity and impacts of an 1812 hurricane making landfall near New Orleans, Louisiana, U.S.A. Wheeler et al. (2009) used historical data including ships' logbooks to reconstruct the track of a hurricane in August 1680 and Chenoweth and Mock (2013) used historical records to uncover the earliest U.S. landfalling hurricane in May, 1863.

In the Western North Pacific basin, Chan and Shi (2000) and Liu et al. (2001) used historical records from China to document typhoon landfalls as far back as 1000 A.D. Elsner and Liu (2003) and Fogerty et al. (2006) also used long-term records from China to document and analyze typhoon landfalls in the $17^{\text {th }}$ to $19^{\text {th }}$ centuries. García-Herrera et al. (2007b) and Ribera et al. (2008) made extensive use of historical documents in developing a history of typhoons affecting the Philippines from 1566 to 1900. Kubota and Chan (2009) used historical observation records of tropical cyclone tracks during the period 1901 to 1940 to document typhoon landfalls in the Philippines.

For Japan, Grossman and Zaiki (2007) used data from historical documents to reconstruct typhoon frequencies affecting the islands from 1801 to 1830 , to estimate the tracks of some historical typhoons in the 19th century (Grossman and Zaiki, 2008), and to reconstruct a chronology of typhoons affecting Japan in the 1880s (Grossman and Zaiki, 2009). For specific storms, Konishi (2010) used historical documents to describe the 1828 Siebold Typhoon and its storm surges and Sakasaki, et al. (2015) applied historical, geological, and meteorological research to reconstructing the track, meteorology and damages from a strong typhoon in 1856.

Although Japan has a long history of written record-keeping, systematic instrumental climatological records have only been kept since the founding of the Imperial Meteorological Observatory (IMO) in 1875 and weather maps have only been published since 1883 . Further, these records are limited in detail and spatial coverage. For 1877, only data from Tokyo were available. Thus, there is a need to use other data sources to reconstruct a detailed record of typhoons in the late $19^{\text {th }}$ century.

\section{Data and methods}

In this section, the data and methods used to document the typhoons affecting Japan in 1877 are described. It should be noted that while 
modern typhoons are defined and classified by wind speed, accurate wind speed data are not usually available for historical typhoons. For the present discussion, we consider a tropical cyclone to be a typhoon based on varying combinations of wind speeds and directions, heavy rains, low barometric pressures, relatively short duration (one to three days), direction of movement, and impacts (e.g., fatalities or injuries, damage to structures or to ships).

Wind speed equivalents suggest that a tropical cyclone with winds of 8 or above on the Beaufort Wind Force and 5 or above on the Simplified Beaufort Wind Force scales (Table 1) would be considered a typhoon according to the Japan Meteorological Agency's standard that a typhoon should have winds above 17.5 $\mathrm{m} / \mathrm{sec}$. In their reconstructions of typhoons making landfall in the Philippines, Kubota and Chan (2009) considered the $1000 \mathrm{hPa}$ threshold to be an acceptable criterion for defining a landfalling typhoon. We use the same criterion here.

Table 1 Wind force equivalents.

\begin{tabular}{clcc}
\hline $\begin{array}{c}\text { Beaufort } \\
\text { Wind } \\
\text { Force }\end{array}$ & \multicolumn{1}{c}{$\begin{array}{c}\text { Wind } \\
\text { Description }\end{array}$} & $\begin{array}{c}\text { Limits of } \\
\text { Wind Speed } \\
\text { m/sec }\end{array}$ & $\begin{array}{c}\text { Simplified } \\
\text { Beaufort } \\
\text { Wind Force }\end{array}$ \\
\hline 0 & Calm & $<1$ & 0 \\
1 & Light air & $1-2$ & 1 \\
2 & Light breeze & $2-3$ & 1 \\
3 & Gentle breeze & $4-5$ & 2 \\
4 & Moderate Breeze & $6-8$ & 3 \\
5 & Fresh Breeze & $9-11$ & 3 \\
6 & Strong Breeze & $11-14$ & 4 \\
7 & Near Gale & $14-17$ & $4-5$ \\
8 & Gale & $17-21$ & 5 \\
9 & Strong Gale & $22-24$ & 5 \\
10 & Storm & $25-28$ & 5 \\
11 & Violent Storm & $29-32$ & 6 \\
12 & Hurricane & $33+$ & 6 \\
\hline
\end{tabular}

Comparison of wind force for the Beaufort Scale, Simplified Beaufort Scale and modern equivalents. The Simplified Beaufort Scale was used by Japanese lighthouses in the Meiji Period. (Source: United Kingdom Meteorological Office $^{1)}$ )

\section{1) English-language newspapers}

An important source of information about typhoons affecting Japan before the period of systematic instrumental data collection is English-language newspapers published in Japan.

These newspapers began to be published in the 1850s. They discussed domestic, local and international events, trade and shipping and weather and disaster news, including typhoon landfalls. The newspapers sometimes included excerpts from ship logs, reports from voyages around Japan and internationally, and landbased instrumental weather data. (See Grossman and Zaiki, 2009, 2013 for further discussion of using English-language newspapers in reconstructing past typhoons in Japan.)

To find reports of typhoons, we carried out page by page searches of the available newspapers for the months of the typhoon season. We found information about typhoons in 1877 in The Japan Weekly Mail and The Japan Gazette, including long and short articles, meteorological tables, and reports from ships in the area during the storms. The newspapers provide dates and times, locations, descriptions of weather conditions, damage and, in some case, barometric pressures.

2) Historical Weather Database for Japan

The Historical Weather Database for Japan (HWD) (Yoshimura, 1993) was constructed from historical documents such as diaries of feudal clans, local offices, temples, shrines, farms and private individuals. Japanese historians and climatologists read the original documents, extracted daily weather descriptions, and coded them into the database.

The researchers assigned alphanumerical codes to the qualitative descriptions of daily weather (e.g., $1=$ clear, fine; $2=$ sunny, partly cloudy; $8=$ rain; $9=$ heavy rain, $\mathrm{D}=$ snow, heavy snow) and used these codes to report the range of best and worst weather for the day. Wind strength and direction and additional information regarding weather conditions were also coded into the database.

If the researchers could infer the presence of a typhoon, it was recorded as such (Yoshi- 
mura, 1993). We accepted the judgments of the researchers about the presence of a typhoon as a starting point for examining other sources. (See Grossman and Zaiki, 2009 and 2013 for a discussion of using the HWD for reconstructing typhoon histories.)

To find typhoons affecting Japan in 1877, we extracted diary entries for that year from the full $19^{\text {th }}$ century data set. Five diaries from five locations included 1877. We filtered these entries for the main months of the typhoon season (June-October). To capture likely typhoons, we then filtered the entries for records coded with " $T$ " for typhoon and for strong wind and heavy rain or strong wind and rain. These conditions match the meanings implied by the terms boufu (strong wind), boufuu or daifuu (strong wind and rain), and daifu or ookaze (strong wind) found in many historical descriptions. The results matched the four typhoons found in the English-language newspapers.

\section{3) Ship logs}

With the opening of Japan to international trade and shipping after Admiral Perry's missions in the 1850's, visits to ports in Japan by U.S. and British Navy ships became more frequent. Logs from these ships can be used to document typhoons affecting Japan as many of the ships were in port or near Japan during the storms. Extensive research in U.S. and U.K. National Archives, the British Library and the U.S. Library of Congress by Mock uncovered 19 British and U.S. Navy ship logs with information about typhoons affecting Japan in 1877. (See Mock, 2012 for further discussion of the use of ship logs in typhoon reconstruction.) All four of the typhoons found in the newspapers and the HWD were found in the ship logs. One additional log from Nagasaki/Kobe suggested another possible typhoon on September 8. However, additional information about this storm has not yet been found.

\section{4) Japanese lighthouse records}

Japan began to build lighthouses in 1866 and, in 1868, R.H. Brunton, a British engineer, was invited by the Japanese government to supervise the construction of lighthouses around the country. The collection of systematic meteorological observations at lighthouses began after 1872 (Nyomura, 2002). By 1877, meteorological observations were being recorded twice a day at 26 lighthouses operating along the coast. The data collected included air pressure, temperature, precipitation, wind directions/wind force, cloud types/cloud amounts and weather descriptions. These data were preserved on microfilm and recently, as image files, by the Japan Meteorological Agency.

For our investigation of the typhoons of 1877 , we used digitized twice-daily reports from 26 lighthouses. We filtered the data for winds of Force 5 or greater based on a simplified version of the Beaufort classification (Force 0 to 6) used by the lighthouses during the Meiji Period (1868-1912) (Nyomura, 2002) (Table 1). This resulted in eight daily reports. We also filtered the data set for reports of Wind Force 4 and barometric pressures of less than $990 \mathrm{hPa}$. This resulted in 19 additional reports. It should be noted that the pressure readings are preliminary as it is not yet been determined if all the pressures were adjusted for temperature. All four typhoons found by the other data sources were also found in the lighthouse search.

5) Japanese government meteorological observations

The last of the sources in this study is daily instrumental weather data published after 1875 by the Japan Imperial Meteorological Observatory in monthly tables (IMO, 1877). Data (barometric pressure, air temperature, wind speed and direction, and cloudiness) for 1877 are limited as they were only collected in Tokyo.

\section{Typhoons of 1877}

All five of our sources provide evidence documenting four typhoons affecting the main islands of Japan in 1877. The first, on June 11 , occurred early in the typhoon season. In the modern record (1951-2011), only $8.7 \%$ of typhoon coming near Japan do so in June. The second (July 26-27) and third storms (August 25-27) reached Japan during the peak months 


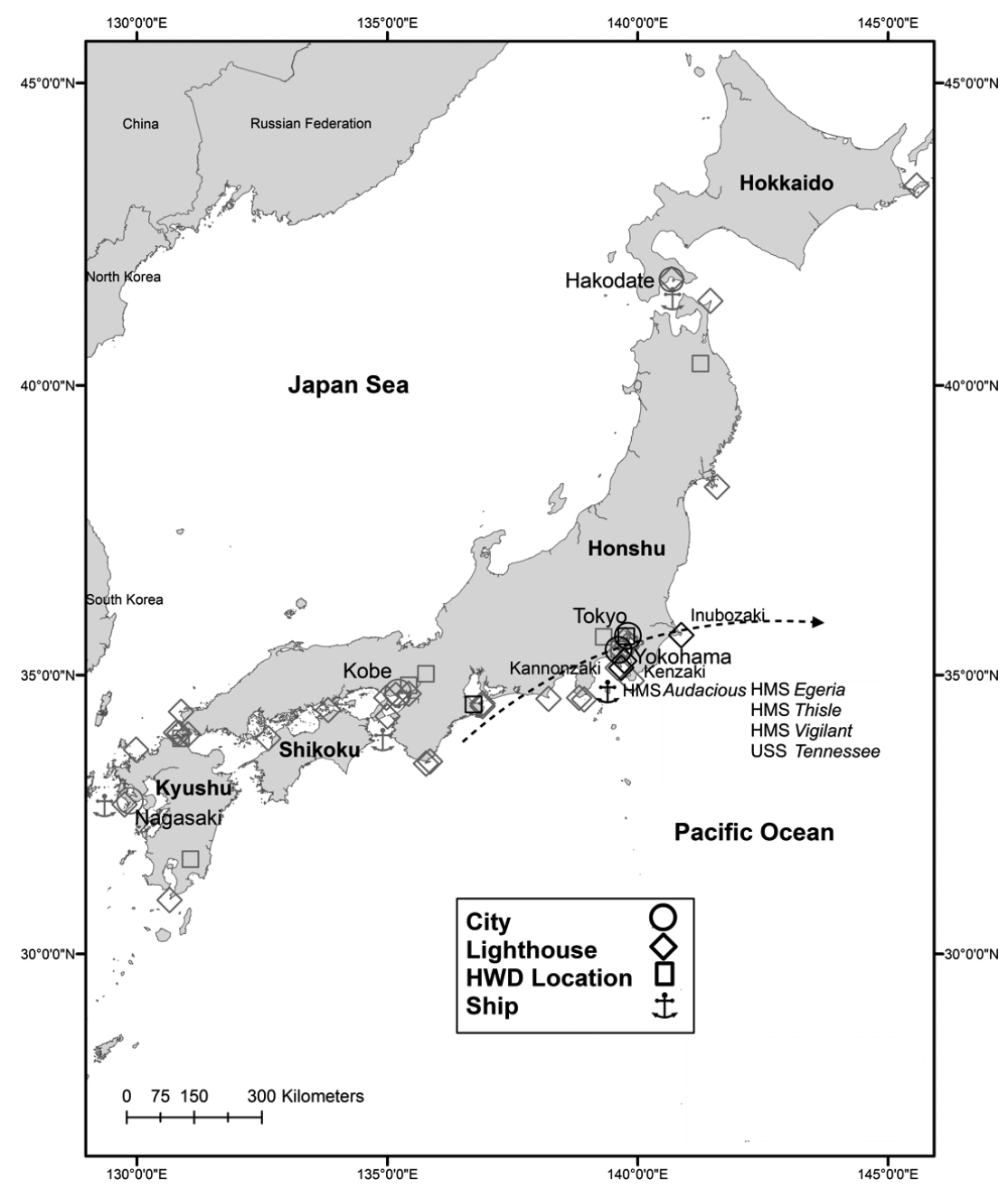

Fig. 1 Data source locations for the June 11 typhoon. Data source locations are in Bold. Dotted line is estimated track of the typhoon. HMS is the prefix used for British Navy ships. USS is the prefix used United States Navy ships. The Kanto region is the area surrounding Tokyo as described in the text. The Kinki region is the area around Kobe as described in the text.

of the typhoon season. The fourth typhoon (October 11) occurred late in the season when only about $10.3 \%$ of typhoons coming near Japan do so (Grossman et al. 2015). Here, we describe the evidence for each of these storms.

\section{1) Typhoon of June 11}

Figure 1 shows the locations of the data sources for this typhoon.

On June 12, 1877, The Japan Gazette reported.

Yesterday evening a severe gale commenc- ed, lasting until early this morning. The lowest reading of the barometer on shore was $29.35(993.91 \mathrm{hPa})$ at about half past ten p.m.; and the storm was at its height shortly after that hour. Although several fences were overthrown, some chimneys blown down, portions of roofs and verandahs carried away, and plaster striped off the sides of houses, we hear of no personal injury having been sustained by anyone on shore. 
The newspaper reported additional barometric pressure readings, wind force and direction and described the effects of the typhoon on ships in Yokohama harbor. Also, included was a table of Meteorological Observations from the U.S. Naval Hospital at Yokohama indicating a strong gale with a minimum barometric pressure of $988.83 \mathrm{hPa}$.

The HWD included two entries for June 11 referring to a typhoon with heavy rain and strong wind at Ise and heavy rain and strong winds in Tokyo.

The lighthouse records for June 11 indicated south winds of Force 4 on the Simplified Beaufort scale (See Table 1) at three locations (Inubozaki, Kannonzaki, and Kenzaki (Tsurugisaki)) on the Pacific Coast east of the TokyoYokohama area with a minimum barometer reading of $975.96 \mathrm{hPa}$ at Inubozaki.

Four British Navy ships (HMS Audacious, HMS Egeria, HMS Thistle, and HMS Vigilant) were in Yokohama Harbor on June 11-12. Data from their logs indicated that a typhoon struck the area between 6:00 p.m. on June 11 and 4:00 a.m. on June 12. All four British ships reported SSW winds of between 8 and 10 on the Beaufort scale. Weather was overcast with squalls and minimum barometric pressures reported were $991.20 \mathrm{hPa}, 992.21 \mathrm{hPa}, 1001.69 \mathrm{hPa}$, and $996.61 \mathrm{hPa}$, respectively.

The USS Tennessee was also in Yokohama Harbor on June 11-12. Its logs reported that between 6:00 p.m. June 11 and 4:00 a.m. on June 12, winds were Force 8 or 9 on the Beaufort scale. The weather was overcast with squalls and a minimum barometric pressure of $1001.36 \mathrm{hPa}$.

Data from the Imperial Meteorological Observatory in Tokyo indicated winds shifting from S to WSW to SSW throughout the afternoon and night of June 11 with speeds up to $15.2 \mathrm{~m} / \mathrm{s}$. Weather was overcast with a minimum barometric pressure on June 11 of 993.23 $\mathrm{hPa}$.

The locations and timing of reports, wind speeds and direction changes, minimum pressures, rain and damage all indicate a typhoon affecting the Kanto region of east central Honshu Island on the Pacific Coast side of Japan on that day. The Kanto region includes the Tokyo Metropolitan area and six prefectures: Gunma, Tochigi, Ibaraki, Saitama, Chiba, and Kanagawa.

\section{2) Typhoon of July 26-27}

Figure 2 shows the locations of the data sources for this typhoon.

On July 28, 1877, The Japan Weekly Mail reported.

The unusually long continued dry and hot weather was broken up yesterday by a violent storm of wind and rain. It began to blow up about 9 a.m., but the wind did not attain any great force until shortly after midday. It then blew gusts with great violence until evening... Everything indicated that we had been on the Northern semicircle of a typhoon traveling from East towards the West, the centre passing South of us about 4 p.m. There was a novelty in this typhoon coming in from the Eastward, a fact which has perhaps never before been observed in Yokohama by foreigners.

The story continues describing the wrecking of ships and smaller boats by the storm and includes some pressure readings showing a minimum pressure of $997.97 \mathrm{hPa}$ recorded on the $26^{\text {th }}$ at 7:00 $\mathrm{pm}$.

Three additional stories in The Japan Gazette and a Meteorological Table from the U.S. Naval Hospital at Yokohama also indicate that a strong typhoon affected Yokohama on July 26-27. One Japan Gazette story from August 1 describes the wrecking of a Danish ship and an American ship and many smaller boats by the storm. The Naval Hospital report indicated overcast skies with passing showers and rain, shifting winds and a minimum barometric pressure $994.58 \mathrm{hPa}$ at 9:00 p.m. on the 26th.

Our search of the HWD found three entries for a July 26 storm. All three (Hachioji, Yokohama and Tokyo) reported strong winds and heavy rain. The entry for Hachioji had the special comment indicating a typhoon.

The lighthouse records had one report 


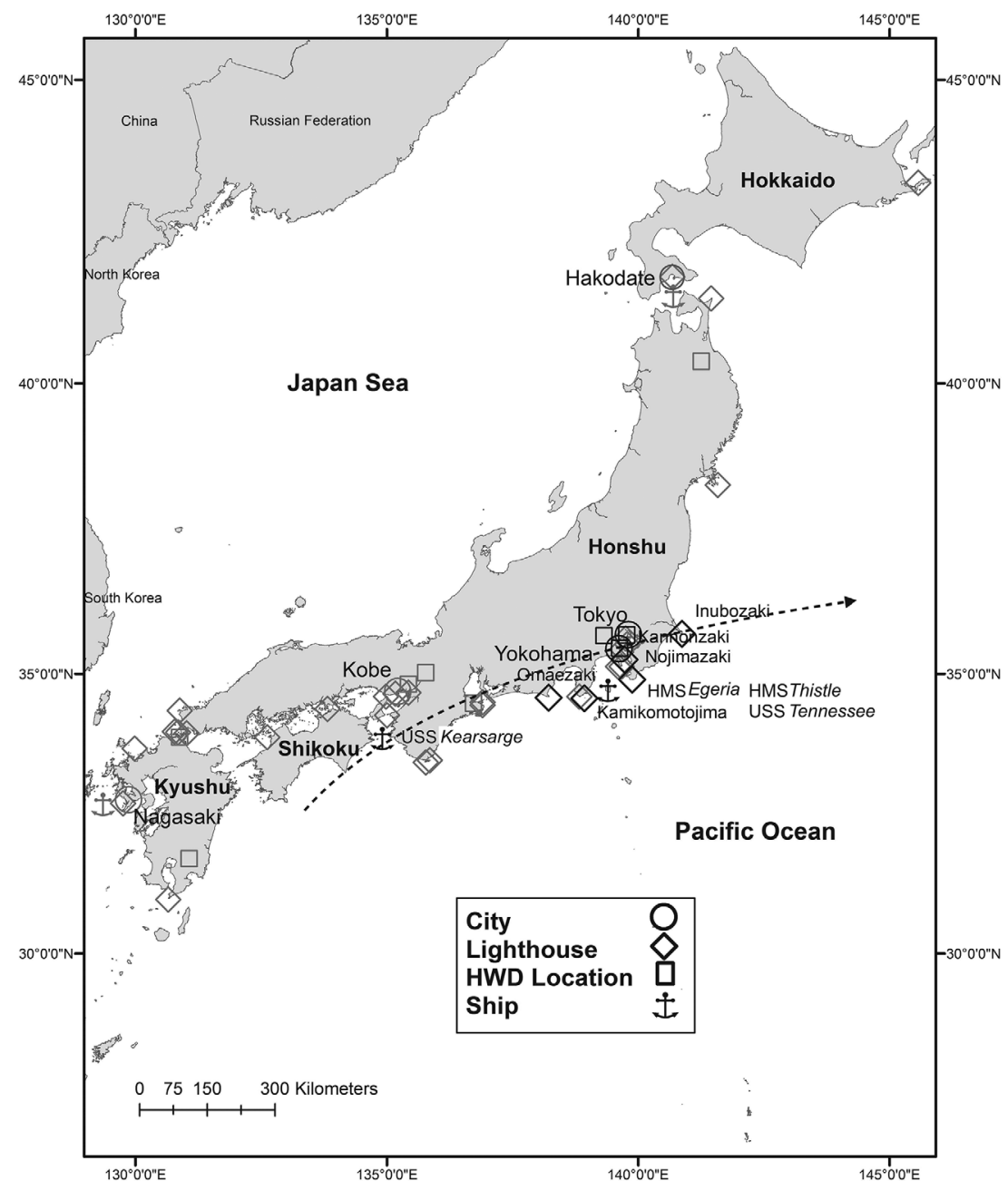

Fig. 2 Same as Fig. 1 except for the July 26-27 typhoon.

(Nojimazaki) for July 26 with winds of Simplified Beaufort Force 5 and a minimum pressure of $1005.76 \mathrm{hPa}$.

Four additional lighthouses (Kamikomotoshima, Omaezaki, Inubozaki, and Kannonzaki) along the Pacific Coast of Japan reported winds of Simplified Beaufort Force 4. Pressures reported at the six lighthouses ranged from $976.63 \mathrm{hPa}$ to $988.49 \mathrm{hPa}$.

Two British Navy ships (HMS Egeria and HMS Thistle) and one U.S. Navy ship (USS Tennessee) were in Yokohama Harbor and the USS Kearsarge was at Kobe on July $26-27$. The log from the HMS Thistle for July 26 indicates shifting winds of Force 7-10 between 12:00 p.m. on the $26^{\text {th }}$ and 2:00 a.m. on the $27^{\text {th }}$. The HMS Egeria logs similarly indicate shifting winds of Force 8-10 between 11:00 p.m. and 5:00 a.m. on those days. Minimum pressure recorded on the Thistle was $1004.06 \mathrm{hPa}$ at 6:00 p.m. on the $26^{\text {th }}$ and on the Egeria 997.29 hPa at 5:00 p.m. on that day.

The USS Tennessee also reported similarly shifting winds of Force 7-9 in the afternoon and evening of the $26^{\text {th }}$. The minimum pressure reported was $1002.37 \mathrm{hPa}$. In the early after- 
noon of the $26^{\text {th }}$, the USS Kearsarge in Kobe briefly reported winds of Force 6 with pressures falling throughout the afternoon and evening to a minimum of $1003.39 \mathrm{hPa}$ at 8:00 pm. Squalls with sudden shifts of wind were also reported in the early afternoon.

Data from the Imperial Meteorological Observatory in Tokyo indicated a minimum pressure of $999.32 \mathrm{hPa}$ at $3: 30 \mathrm{p} . \mathrm{m}$. on the $26^{\text {th }}$ with winds shifting between 3:00 and 10:00 p.m. at speeds of up to $16.1 \mathrm{~m} / \mathrm{s}$. Weather was overcast with 1.97 inches of rain reported.

The locations and timing of reports, wind speeds and direction changes, minimum pressures, rain and damage indicate that the typhoon approached from the east and primarily affected the Kanto area of central Honshu Island on the Pacific Coast side of Japan though it seems to have skirted the coast in the Kinki region of west-central Honshu on its approach. The Kinki region includes the prefectures of Hyogo, Nara, Shiga, Wakayama, and Mie and the urban prefectures of Kyoto and Osaka.

\section{3) Typhoon of August 25-27}

Figure 3 shows the locations of the data sources for this typhoon.

A reference by the American Steamer City of Tokio to an encounter with a strong gale on August 25 appeared in The Japan Gazette on August $29^{\text {th }}$.

Hove to, head to S. and E. to avoid centre of typhoon, approaching from S.W. At this time, strong gale from E.E. At 1 p.m. gale had increased to hurricane force, from S.E. to SS.E. with furious cross, and pyramidal sea, and tremendous rollers from S. and W. At 7 p.m., wind hauling to S.W. and moderating to 10 Force... Barometer $992.21 \mathrm{hPa}$.

It is not clear exactly where the ship was at the time of its encounter with the typhoon although the description indicates the ship's arriving in Yokohama on August $26^{\text {th }}$ suggesting that the encounter was near Japan. Further, an entry in the HWD for August $26^{\text {th }}$ indicates strong winds and heavy rain in Tokyo on that day. In addition, an entry in Historical Records of the Climate of Japan (Central and Marine
Observatory, 1976), reported a typhoon on August 26 in Fukuoka and Tochigi Prefectures with strong winds and rain and damage to trees in Fukuoka in western Japan.

The lighthouse records include two reports of winds of Force 5 (Tomogashima and Kinkazan). The lighthouse at Tsunoshima reported pressure at 997.29 $\mathrm{hPa}$ and Kinkazan at 992.21 $\mathrm{hPa}$. In addition, there was one lighthouse report (Tomogashima) of winds of Force 4 on the $26^{\text {th }}$ and two (Inubozaki and Kamikomotoshima) on the $27^{\text {th }}$.

In late August 1877, there were four British Navy and three U.S. Navy ships around Japan. The USS Kearsarge, in Nagasaki on the $26^{\text {th }}$, reported shifting winds increasing from Force 4 at 12:00 a.m. to Force 7 by 6:00 a.m. and then to Force 10 by 8.00 am. Minimum pressure reported was $978.67 \mathrm{hPa}$ at 10:00 a.m. on the $26^{\text {th }}$.

Two British ships were in Kobe on August $26^{\text {th }}$. The HMS Sylvia reported strong shifting winds of up to Force 7 from 12:00 p.m. increasing to up to Force 10 by 8:00 p.m. with a minimum pressure of $1005.42 \mathrm{hPa}$ at $4: 00$ and 8:00 pm. The HMS Egeria reported strong shifting winds of up to Force 5 increasing to up to Force 7 by 8:00 p.m. with minimum pressure of $1003.39 \mathrm{hPa}$ at $6: 00 \mathrm{pm}$.

Three ships were in Yokohama on the $26^{\text {th }}$ and $27^{\text {th }}$. The HMS Thistle reported shifting winds of up to Force 4-5 from 4:00 p.m. increasing to up to Force 6 at 12:00 a.m. and to Force 8 by $4: 00$ a.m. on the $27^{\text {th }}$. Minimum pressure was $1009.82 \mathrm{hPa}$ at 6:00 a.m. on the $27^{\text {th }}$. The USS Alert Yokohama reported winds increasing in force from between Force 3-6 to Force 4-7 by 12:00 am. Throughout the morning of the $27^{\text {th }}$, the winds continued to increase up to Force 89 by 5:00 am. Minimum pressure reported was 1004.74 $\mathrm{hPa}$ at 5:00-6:00 a.m. on the $27^{\text {th }}$. The USS Tennessee reported that beginning about 4:00 p.m. on the $26^{\text {th }}$, winds began to increase from between Force 4 to Force 6 by 12:00 am. On the morning of the $27^{\text {th }}$, winds continued to increase up to Force 8 between 2:00-4:00 a.m. before decreasing throughout the morning. 


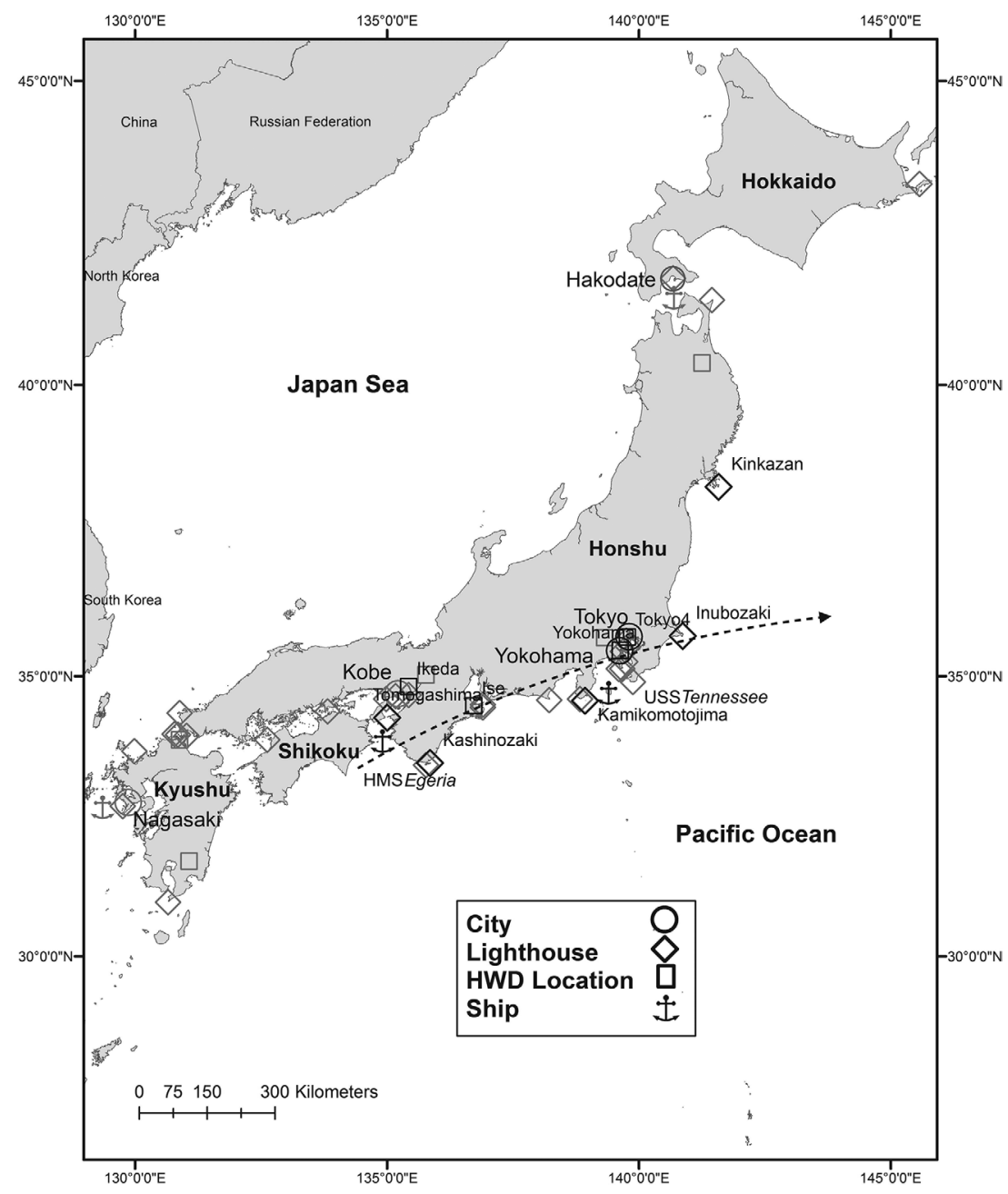

Fig. 3 Same as Fig. 1 except for the August 25-27 typhoon.

Minimum pressure reported was $1000.34 \mathrm{hPa}$ at 4:00 a.m. on the $27^{\text {th }}$.

The HMS Audacious was in Hakodate in southern Hokkaido. On the $27^{\text {th }}$, shifting winds began increasing from Force 4-5 from 5:00 a.m. increasing to $5^{-7}$ by 11:00 a.m. with minimum pressure reported at $993.57 \mathrm{hPa}$ at 10:00 a.m. on the $27^{\text {th }}$.

Data from the Imperial Meteorological Observatory in Tokyo indicated a minimum pressure of $999.32 \mathrm{hPa}$ at 3:30 p.m. on August $26^{\text {th }}$ with winds shifting from the NE to the SE between 3:00 and 10:00 p.m. at speeds of up to $16.1 \mathrm{~m} / \mathrm{s}$.
Weather was overcast with 1.965 inches of rain reported on the $26^{\text {th }}$.

The location and timing of the reports, wind speeds and direction changes, pressures, rain and damage all indicate a typhoon. The typhoon seems to have passed over Kyushu, then over the Kinki region of west central Japan, to Kanto in central Honshu before affecting southern Hokkaido on its way out to sea.

\section{4) Typhoon of October 11}

Figure 4 shows the locations of the data sources for this typhoon.

The Japan Gazette of October $11^{\text {th }}$ included a 


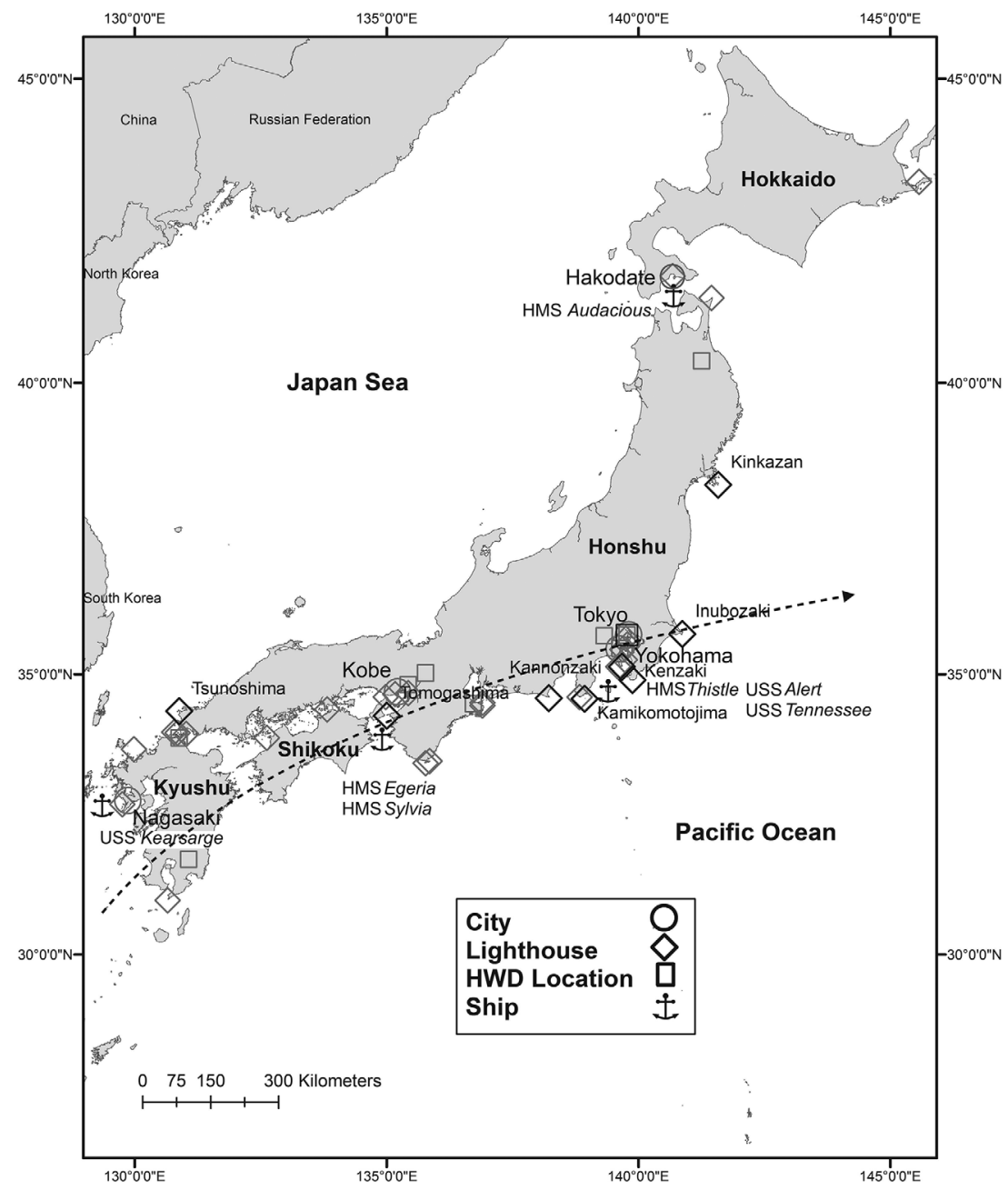

Fig. 4 Same as Fig. 1 except for the October 11 typhoon.

short report of a strong gale.

As we go to press, a strong gale is blowing. The barometer has fallen quite sixteenths since this morning at seven o'clock, but is now rising. Damage has already been done to several houses, our own office among others, in the settlement: and the Bluff residences are having a rather bad time of it.

The Japan Gazette for October 12 included a longer story describing damage in Yokohama and "severe effects" including damage to buildings and trees in Tokyo. The same issue includ- ed a Meteorological Table from the U.S. Naval Hospital at Yokohama which mentioned a strong gale with $\mathrm{S}$ winds and a minimum pressure of $991.53 \mathrm{hPa}$ at 3:00 p.m. on the $11^{\text {th }}$.

The HWD included four entries for an October $11^{\text {th }}$ storm. Three of the entries (Ikeda, Yokohama and Tokyo) reported strong winds and heavy rain with the fourth (Ise) reporting strong winds and rain. The entry for Ise had the special comment indicating a typhoon.

The lighthouse records included two reports (Kamikomotoshima and Kinkazan) for October $11^{\text {th }}$ with winds of Force 5 . Kamikomotoshima 
reported pressure at $995.60 \mathrm{hPa}$ and Kinkazan at $986.79 \mathrm{hPa}$. In addition, there were three lighthouse reports (Tomogashima, Inubozaki and Kashinozaki) of winds of Force 4 with pressures of 976.97, 987.81, and 982.82, respectively.

In October 1877, there was one British Navy ship in Kobe and one U.S. Navy ship in Yokohama. The HMS Egeria reported shifting winds from Force 3-4 throughout the morning of the $11^{\text {th }}$ increasing to Force 10 by 12:00 p.m. with the lowest pressure at $980.36 \mathrm{hPa}$ at 12:00 pm. The USS Tennessee, further east in Yokohama, reported shifting winds increasing from Force 3 around 10:00 a.m. to Force 10 by $5: 00 \mathrm{pm}$. Strong winds continued throughout the evening until early morning of the $12^{\text {th }}$. The minimum pressure reported was $994.24 \mathrm{hPa}$ at 4:00 p.m. on the $11^{\text {th }}$.

Data from the Imperial Meteorological Observatory in Tokyo indicated a minimum pressure of $991.20 \mathrm{hPa}$ at 3:30 p.m. on October $11^{\text {th }}$ with winds shifting from the $\mathrm{W}$ to the SE to the SSW between 3:00 a.m. and 10:00 p.m. at speeds of up to $11.2 \mathrm{~m} / \mathrm{s}$.

The locations and timing of reports, wind speeds and direction changes, minimum pressures, rain and damage indicate that the typhoon primarily affected the Kanto area of central Honshu Island on the Pacific Coast side of Japan.

\section{Concluding remarks}

Evidence from multiple sources is important when using historical documentary evidence to reconstruct climatic events of the past, such as typhoons. The data and reports from the multiple sources described here indicate that at least four typhoons made landfall or came close to land in 1877. Four typhoons making landfall or coming close to land on the main islands would be slightly more than the modern average of 3.1 per year (JMA, 2017c). All of the typhoons affected the Tokyo-Yokohama area and the locations of other reports suggest that all four likely followed Pacific Coast tracks. Studies of typhoon tracks using modern records (Gross- man et al., 2015, 2016) show that during the period 1951-2013, about half of all typhoons coming close to Japan follow Pacific Coast tracks and half follow Japan Sea tracks with variability at annual and decadal time scales. It appears that 1877 was an unusual year with all four typhoons following Pacific Coast tracks.

A lack of data sources on the Japan Sea side somewhat limits our conclusions about the tracks of these typhoons. However, a future detailed analysis of wind forces, wind directions and pressures should make it possible to better reconstruct the timing and tracks of the four typhoons. This will also enable us to estimate the strength of the storms and to compare them with modern tropical cyclones that were of similar strength and followed similar tracks. Similar data to what we have used here are also available for the period 1878-1882 and will be used to develop a detailed record of typhoons affecting Japan in the years just prior to official weather mapping by the Japan Meteorological Agency.

\section{Acknowledgements}

This work was supported by JSPS Grant-in-Aid for Scientific Research (B) Grant Number 25282085 and $16 \mathrm{H} 03116$.

\section{Notes}

1) Source: United Kingdom Meteorological Office. http://www.metoffice.gov.uk/guide/weather/marine/ beaufort-scale [Cited 2017/7/24].

\section{References}

Central and Marine Observatory (1976): Historical Records of the Climate of Japan. Volume 1 (Nihon No Kisho Shiryo). Hara Shobou, 404p. (in Japanese)*.

Chan, J.C.L. and Shi, J. (2000): Frequency of typhoon landfall over Guangdong Province of China during the period 1470-1931. International Journal of Climatology, 20, 183-190.

Chenoweth, M. (2014): A new compilation of North Atlantic tropical cyclones, 1851-98. Journal of Climate, 27, 8674-8685.

Chenoweth, M. and Mock C.J. (2013): Hurricane "Amanda": Rediscovery of a forgotten U.S. Civil War Florida hurricane. Bulletin of the American Meteorological Society, 94, 1735-1742.

Elsner, J.B. and Liu, K. (2003) . Examining the ENSO- 
typhoon hypothesis. Climate Research, 25, 43-54.

Fogarty, E.A., Elsner, J.B., Jagger, T.H., Liu, K. and Louie, K. (2006): Variations in typhoon landfalls over China. Advances in Atmospheric Sciences, 23, 665-677.

García-Herrera, R., Duran, F.R., Wheeler, D., Hernández, E., Prieto, M.R. and Gemeno, L. (2004): The use of Spanish and British documentary sources in the investigation of Atlantic hurricane incidence in Hurricanes and Typhoons: Past, Present, and Future edited by Murnane R. and Liu, K.B., Columbia University Press, 149-176.

García-Herrera, R., Gimeno, L., Ribera, P. and Hernández, E. (2005): New records of Atlantic hurricanes from Spanish documentary sources. Journal of Geophysical Research, 110:D03109, doi:10.1029/ 2004JD005272.

García-Herrera, R., Gimeno, L., Ribera, P., Hernández, E., González, E. and Fernández, G. (2007a): Identification of Caribbean Basin hurricanes from Spanish documentary sources. Climatic Change, doi: 10.1007/ s10584-006-9124-4.

García-Herrera, R., Ribera, P., Hernández, E. and Gimeno, L. (2007b): Northwest Pacific typhoons documented by the Philippine Jesuits, 1566-1900. Journal of Geophysical Research, 112, D06108, doi: 10.1029/2006JD007370.

Grossman, M. and Zaiki, M. (2007): Reconstructing typhoon landfalls in Japan from historical documentary records 1801-1830. in Papers of the Applied Geography Conferences October 17-20, 2007 edited by Harrington, L.M.B. and Harrington Jr., J.A., 30, 334-343.

Grossman, M. and Zaiki, M. (2008): Reconstructing typhoon landfalls in Japan in the 19th Century using GIS in Papers of the Applied Geography Conferences October 15-18, 2008 edited by Harrington, L.M.B. and Harrington Jr., J.A., 31, 152-161.

Grossman, M. and Zaiki, M. (2009): Reconstructing typhoons in Japan in the 1880s from documentary records. Weather, 64, 315-322.

Grossman, M.J. and Zaiki, M. (2013): Documenting 19th century typhoon landfalls in Japan. Review of Asian and Pacific Studies. Center for Asian and Pacific Studies, 38, 95-118.

Grossman, M.J., Zaiki, M. and Nagata, R. (2015): Interannual and interdecadal variations in typhoon tracks around Japan. International Journal of Climatology, 35, 2514-2527.

Grossman, M.J., Zaiki, M. and Oettle, S. (2016): An analysis of typhoon tracks around Japan using ArcGIS. Papers in Applied Geography, 2, 352-363.

Imperial Meteorological Observatory (IMO) (1877): Monthly Weather Tables. Japan Imperial Meteorological Observatory.

Japan Meteorological Agency (JMA) (2017a): Number of occurrences of typhoons in the Western North
Pacific.

http://www.data.jma.go.jp/fcd/yoho/typhoon/statistics/generation/generation.html [Cited 2017/03/17].

Japan Meteorological Agency (JMA) (2017b) : Number of typhoons approaching Japan. http://www.data.jma.go.jp/fcd/yoho/typhoon/statistics/accession/accession.html [Cited 2017/03/17].

Japan Meteorological Agency (JMA) (2017c): Number of typhoons making landfall on the Japan main islands (Honshu, Hokkaido, Kyushu, Shikoku). http://www.data.jma.go.jp/fcd/yoho/typhoon/statistics/landing/landing.html [Cited 2017/03/17].

Kitamoto, A. (2017): Digital Typhoon, Typhoon Damage Database.

http://agora.ex.nii.ac.jp/cgi-bin/dt/disaster.pl?lang= en\&basin=wnp\&sort=damage\&order=dec\&stype $=$ number [Cited 2017/03/17].

Konishi, T. (2010): Siebold Typhoon in 1828 (otherwise "Nenotoshi Typhoon") and induced storm surges. Tenki, 57, 383-398. (in Japanese)

Kubota, H. and Chan, J.C.L. (2009): Interdecadal variability of tropical cyclone landfall in the Philippines from 1902 to 2005. Geophysical Research Letters, 36, L12802, doi:10.1029/2009GL038108.

Liu, K., Shen, C. and Louie, K. (2001): A 1000-year history of typhoon landfalls in Guangdong, Southern China reconstructed from Chinese historical documentary records. Annals of the Association of American Geographers, 91, 453-464.

Mock, C.J. (2004): Tropical cyclone reconstructions from documentary records: Examples from South Carolina, in Hurricanes and Typhoons: Past, Present and Future edited by Murname, R.J. and Liu, K.-B., Columbia University Press. 121-148.

Mock, C.J. (2008): Tropical cyclone variations in Louisiana, U.S.A., since the late eighteenth century. Geochemistry, Geophysics, Geosystems, 9, Q05V02, doi:10.1029/2007GC001846.

Mock, C.J. (2012): Early-instrumental and documentary evidence of environmental change. in The SAGE Handbook of Environmental Change: Volume 1: Approaches, Evidences and Causes edited by Matthews, J.A., Sage Publications, 345-360.

Mock, C.J., Chenoweth, M., Altamirano, I., Rodgers, M.D. and García Herrera, R. (2010): The great Louisiana Hurricane of August 1812. Bulletin of the American Meteorological Society, 91, 1653-1663.

Nyomura, Y. (2002): The important role in Meiji's weather service Meteorological observation at the lighthouse - Lighthouse weather observation materials and history. Weather (Kisho), 539, 1769817704. (in Japanese)*

Ribera, P., García-Herrera, R., Hernández, E. and Gimeno, L. (2008): Historical deadly typhoons in the Philippines. Weather, 63, 194-199.

Sakasaki, T., Kaname, Y., Ohmi, J. and Hattori K. (2015): Damage of the Ansei Edo typhoon (1856) 
and estimation of the meteorological field at that time. Survival Study, 11, 64-70. (in Japanese)

Wheeler, D., García-Herrera, R., Vaquero, J. M., Chenoweth, M. and Mock, C.J. (2009): Reconstructing the trajectory of the August 1680 hurricane from contemporary records. Bulletin of the American
Meteorological Society, 90, 971-978.

Yoshimura, M. (1993): Historical Weather Database and reconstruction of the climate in historical time. Journal of Geography (Chigaku Zasshi), 102, 131143 (in Japanese).

* Title etc. translated by M.Z. 


\section{7 年に日本に影響をおよぼした台風の復元}

\section{Michael J. GROSSMAN* 財城真寿美** 三 上岳彦*** Cary MOCK}

歴史文書は，気象官署による測器を用いた公式 気象観測が開始される以前の台風復元において, 貴重な情報源となる。本稿では, 1877 年の日本 （北海道，本州，四国，九州）に影響をおよほし た台風について，詳細な情報を含む 5 つの資料 （1：日本で出版された英字新聞， 2 : 歴史天候デー タベース，3：日本の灯台気象観測記録，4：イ ギリスおよびアメリカ合衆国の船舶の航海日誌, 5 : 中央気象台の気象観測表）の検証を行った。 そしてこれらすべての資料から，1877 年におい
て日本に上陸もしくは接近した 4 つの台風事例 (6月 11 日， 7 月 26-27日，8 月 25-27日，10 月 11 日）が明らかとなり，歴史文書は，日本に おける暴風雨の位置，移動経路，風速，気圧，被 害などに関する詳細な情報を含んでいることが裏 づけられた。歴史文書に記録された台風に関する 情報は，台風の襲来頻度や強度，挙動に関する理 解を，気象観測や台風観測の詳細な数值データが 十分に得られない過去の時代にまで，さかのぼる 可能性を有しているといえる。

キーワード：熱帯低気圧, 台風, 歴史気候学, 日本, 気候復元, 文書記録

\footnotetext{
* 南イリノイ大学エドワーズヴィル校

** 成蹊大学経済学部

*** 帝京大学文学部

**** サウスキャロライナ大学
} 